Témoigner Témoigner. Entre histoire et mémoire

Getuigen Revue pluridisciplinaire de la Fondation Auschwitz

$123 \mid 2016$

Traduire le témoignage

\title{
Pushing Back: Witnesses and Translation in the Radovan Karadžić Trial
}

\section{Ellen Elias-Bursać}

\section{Q OpenEdition \\ 1 Journals}

\section{Electronic version}

URL: https://journals.openedition.org/temoigner/5325

DOI: 10.4000/temoigner.5325

ISSN: 2506-6390

Publisher:

Éditions du Centre d'études et de documentation Mémoire d'Auschwitz, Éditions Kimé

\section{Printed version}

Date of publication: 1 October 2016

Number of pages: $100-114$

ISBN: 987 2-9600926-4-6

ISSN: 2031-4183

\section{Electronic reference}

Ellen Elias-Bursać, "Pushing Back: Witnesses and Translation in the Radovan Karadžić Trial", Témoigner. Entre histoire et mémoire [Online], 123 | 2016, Online since 02 November 2021, connection on 04 November 2021. URL: http://journals.openedition.org/temoigner/5325 ; DOI: https://doi.org/ 10.4000/temoigner.5325 


\section{Pushing Back \\ Witnesses and Translation}

in the Radovan Karadžić Trial

$\rightarrow$ Ellen Elias-Bursać

(1) Radovan Karadzic (1945)
lived in Sarajevo before the war, working as a psychiatrist. wartime president of Republika Srpska, the Serbian part of Bos
and Herzzegovina, and supreme commander of the Bosnian Serb
amed forces. He was indicted armed forces. He was indicted
by the ICTY in July 1995 and charged with two counts of
genocide; five counts of crimes against humanity four counts
violations of the laws or customs of war (Case Information Sheet),
After the Daytor Peace Accords After the Dayton Peace Accor
went into effect in late 1995 Went into effect in late 1995
Karadzic withdrew from public
life. He was arrested in Belgrade where he had been masquerading as a faith healer and was had
over to the ICTY in 2008 . (2) The autor worked as a (2) The author worked as a
language reviser/translator in the
ITY English translation unit for ICTY English translation unit for

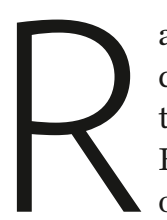

ovan Karadžić, ${ }^{1}$ a powerful political figure in Bosnia and Herzegovin uring the Yugoslav wars, was charged with genocide and war crimes by the International Criminal Tribunal for the former Yugoslavia (ICTY) His trial lasted for four years, with 499 days in court that were recorded on over 48,000 pages of transcripts. Close examination of these proceedings, in which Karadžić chose to defend himself before the court without defence counsel, allows us to identify some of the ways in which witnesses engage with translation and interpreting issues during their testimony for the Prosecution and the Defence. Why the Karadzic ca? consider in terms of witness experience. First, a trial where the defendant conducts his own defence places a particular burden on witnesses: they are examined in court by the alleged war criminal himself. Karadžić perceived his examination of Prosecution and Defence witnesses as an opportunity to dominate, indeed to own, the narrative of the trial. Second, when the Karadžić trial began in 2010 the ICTY had been trying war crimes for over fifteen years. A number of the counts against Karadžić refer to events such as the Srebrenica genocide and the siege of Sarajevo, which had already been heard in testimonies of earlier cases. Hence quite a few of the witnesses had already testified in war-crime proceedings before coming to testify in the Karadžić trial and were no longer novices in the courtroom. Third, Karadžic (n) speaks Enick-andforth use of both languages posed a challenge for the simultaneous interpreter working in the booth. The view of a trial from the booth and the language-service units affords an unusual, sideways perspective on the proceedings that cuts acros parties and politics. Translation is the central axis around which everything at this multilingual Tribunal revolves. ${ }^{2}$ For witnesses to be able to comment on translation issues they must follow the trial in a language other than their own; the amount that witnesses do so is a measure of their agency.

A key question so far for human rights scholars has been whether for victim-witnesses, the act of testifying before a war crimes trial can serve as a viable way to heal, tell their story, and have their tragic experiences heard, recorded, and understood. Eric Stover (2005), Janine N. Clark (2009) and Janes Dawes (2007) an Eric Stover (2005), Janine N. Clark (2009) and James Dawes (2007) analyze the
witnessing experience at the ICTY and the International Criminal Tribunal for
Rwanda (ICTR). Stover's, Dawes', and Clark's research can shed light on aspects of testimony in the Karadžić trial. Stover spoke with 127 people, most of them witnesses, to probe their experience of testifying before a war crimes tribunal "before the accused in a courtroom far from their homes" (Stover 2005, 3-4). Among his many findings was that both parties relied on the narrative of victimhood to describe their situation: "Perpetrators oftent take refuge invictin claims that opposing gethnic group throughut history, and that their own recent acts of aggression were only undertaken to ensure their group's survival" (Ibid.). Stover's analysis of the victimhood which perpetrators claim as their own helps explain Karadžić's own sense of vindication and purpose in waging his trial. He complied with the Tribunal so as to use to full benefit the opportunity his trial gave him to articulate his vision of Republika Srpska and the war.

Whereas Stover raised issues of both the fairness of the ICTY trials, and whether the experience of testifying can help the victim-witnesses deal with the tragedies they have faced, Clark's interviews were conducted in the effort to make "an assessment of the Tribunal's work that is grounded in empirical data" (Clark 2009, 123). After interviewing 65 victims about what they thought of the Tribunal, Clark concluded that about what they thought of the Tribunal, Clark concluded that
"there is little opportunity for victims to tell their stories in their own words", a possibility that has been "further diminished as a result of the move to written testimony at the ICTY" (123-124; 127). Clark's observation about the shift of focus to written testimony speaks directly to the impact the heavy document focus of the Karadžic trial had on shifting attention from victim-witnesses to the tendering of documents.

Dawes based his examination on testimony as a form of storytelling. He describes the conceptual frame of his book as resting on four posts: "the ethics of storytelling the difference storytelling makes, the ethics of human rights and humanitarian work, and the difference this work makes" (Dawes 2007, 7). Like Stovers and Clark, he is concerned with the likelihood of retraumatization: "This contradiction between our impulse to heed trauma's cry for representation and our instinct to protect it from representation - from invasive staring, simplification, dissection - is a split at the heart of human rights advocacy." (9) Dawes' remarks on the witnesses' use of storytelling to battle the regime's noise in the Rwandan war and subsequent war crimes trials offer a parameter for considering Karadžić's particular focus on translation and interpreting in the courtroom as a way to insert himself into the trial, and, in particular, to impose 
While human rights advocacy focuses on testimony that will protect victim-witnesses, not harm them, international criminal courts and tribunals are mandated to offer the accused a fair defence, for without this they would only be providing victor's justice. The question of fairness in these trials is a complicated one and one that does not always protect the witness. Peter Erlinder, a defence attorney at the ICTR explains this to Dawes: “'The real question,' he told me, 'is whether or not questions of fundamental fairness and due process are quso part of the human rights regime"'(Dawes 2007,53 ) This question of fairness becomes all the more pressing in trials of self-represented accused such as Karadžic' where, as we will see, the defendant is vocally involved on every day of the trial. Dawes found that the testimony of the witnesses he spoke to stood up to "genocide as a language war" in which the Rwandan government "worked hard both to silence its opponents and victims and to fill the void it created with noise - in other words, to replace accurate and clear language with lies" (42). This is perhaps the most pertinent point for the Karadžić trial The analysis that follows will sugest that with his ""oisy" antervention, Kary. interventions, Karadžic's strategy was to find ways to use translation and interpreting to drown out the voices of
the witnesses and impose his own. - The bench seated in Courtroom 1 during the
judgement, 24 March 2016

In contrast to Stover, Clark and Dawes, I approach the practice of testifying at the ICTY not through witness interviews but through the analysis of the trial transcripts of every open session of the Karadžić trial available to the public on the ICTY website. While analysis of the transcripts of such a trial cannot offer the persona view an interview provides, it can allow consideration of the involvement of all the witnesses who testified in the trial, both those summoned by the Prosecution and those who came to speak for the Defence, whether they were victim-witnesses, expert witnesses, in-house ICTY experts, ICTY current or past defendants, and even those protected witnesses who testified in open session. In further contrast, the article interrogates the impact of translation-related courtroom strategies, particularly
those of the Defence on witnesses. (3) Rule 92 bis allows admission of written statements and
transcripts in lieu of oral lestimony. This means that
the witness need not attend the trial in person (Rules of Procedure and Evidence, 96). of evidence from a person who provided a written statement or is included in a transcript and
has subsequently died or can no longer with reasonable diligence
be traced (Rules of Procedure and
Evidence 98 .

\section{METHOD}

The research behind this article consists of an analysis of all 41 months of trial as recorded in the transcripts of live testimony given by the 195 Prosecution witnesses (PW) and 238 Defence witnesses (DW). A further 152 witnesses were represented in court by the written statements they gave via Rules 92 bis and 92 quater ${ }^{3}$; thei written testimony is not included in this article. The transeripts were searched witte tre searched lated" "translator", or "translating" from the first day of the trial to the last. This strategy produced a collection of some 3000 comments, 1600 of which are purely procedural in nature: requests for the witness to adjust the microphone, requests for the witness to speak more slowly when testifying so that the booth can keep up, or discussions between the parties when tendering translations for admission. The remaining 1400 are substantive language issues such as disputes over a term, claims of mistranslation, and error correction. On average, there were five or six procedural and/or substantive comments per three-and-a-half-hour session of trial, demonstrating just how pervasive a presence translation and interpreting have in ICTY proceedings.

\section{RADOVAN KARADŽIĆ AND TRANSLATION}

Radovan Karadžić speaks English well, so the Tribunal required him to conduct his trial and all communication with the court in English. Although at first he demanded to be allowed to run his trial in Serbian, claiming his English was inadequate to the task, once the Tribunal insisted that his knowledge of English sufficed, ${ }^{4}$ Karadžić undertook running his trial in both Serbian and English with gusto. When speaking in court he often switched between the two languages. This exchange with historian Robert Donia, who was a witness for the Persecution (PW), illustrates the switching

THE ACCUSED: Q. [Interpretation] Thank you. Now l'd like to draw your attention to the next two paragraphs. Izetbegovic asks: "When the engagement of the opposing forces is summed up, how much is that, those that are in the vicinity of Sarajevo and practically surrounding the city? How many of them are there?" And he goes on to say: There are about 6.000 in the city of Sarajevo, more specifically those that are surrounding the city." Now, do you see that they're talking about an encirclement, the surrounding of the city, and not the siege of the city? Do you note that?

THE WITNESS: [In English] A. No, I don’t. You'll need to give me time.

THE ACCUSED: Q. [In English] "There are around 6.000 in the city of Sarajevo, more specifically those that are surrounding the city", or encircling.

[Interpretation] Perhaps a better translation would be "encircling the city".

[In English] "According to our estimate --"

[Interpretation] And in Izetbegovic's question, it says:

[In English] "... of Sarajevo and practically surrounding the city."

(Transcripts from 22 June 2010, 4101-4102)

In this exchange Karadžić switched languages five times in three sentences. ${ }^{5} \mathrm{His}$ custom of moring Ketweenlanguges and his frequentcommentson how doct custom were translated were hallmarks of the trial. Most accused ${ }^{6}$ sit silently behind their
defence counsel throughout. A few have taken the stand to testify but many do not
(4) This dispute is mentioned
in the judgement Prosecutor in the judgement Prosecutorv
Radovan Karadzic in para. 612 , (5) Imagine the challenge this poses for the translation booths.
The interpreter in one booth is translating Karadžićs Serbian words into English, while the interpreter in another booth is
translating his English words into translating
Serbian. (6) Of the 161 people indicted
(as this article goes to press) 80 have been sentenced and 18
acquitted in over 100 trials and appeals. There were 20 guilty pleas and twelve proceedings are 
even do that. Only four others ${ }^{7}$ chose to conduct their own defence, a choice which provides the accused with the opportunity of speaking daily in court. Karadžićs's use of both languages was one of the ways he dominated the courtroom. With his mastery of Serbian he could demonstrate to the judges that he understood better than them what the witnesses were saying, while his mastery of English allowed him to parry with the attorneys for the Prosecution and speak directly to the Chamber. This was a key piece of his defence: his proof that he was not only equal to those holdin the power in the courtroom, but also superior to them with his versatility. Robert the pow in the court (Dona 2015,6) Donif as a narcissist in the courtroom no less thanin publiclife" (Donia 2015, (0). Doni further explains:

Sometimes he lost track of his intended point as a well-conceived question turned into a monologue resembling testimony. These are the traits of a man accustomed to success in persuading those around him and wearing down those who refuse to agree: a bully with a brilliant mind, a sharp tongue, and great dexterity in exercising his impressive skills of persuasion. (3-4)

By unremittingly disputing translations, Karadžić managed to foist himself on the proceedings.

THE DOCUMENTARY EVIDENCE

If a party to an ICTY trial has a document that is relevant to their case and they wish to tender it, they must find a witness who can speak knowledgeably about the document, either as the person who drafted it, signed it, worked with it, or as an expert witness who has worked with similar documents and can vouch for its credibility. The Karadžić trial relied heavily on documents. More than 6500 exhibits were tendered by the Office of the Prosecutor and more than 4500 by the Defence. According to the Judgement Summary (2016, 2), over 190,000 pages of admitted exhibits were added to the trial record, which consisted of over 330000 pages ex total.Karacic was a recument-heavy tral and he predicted what this would mean for the translation services "I'm afraid that at one point in time translation is going to become a bottleneck in these proceedings." (Transcripts from 28 January 2010, 712)

Karadžić brought many untranslated documents to the hearing through which he asserted his ownership of the proceedings. In the course of the trial it became clear that his document-heavy strategy meant he was tendering an amount of documents for which he could not arrange translation. At the beginning of the trial, Judge Kwon cautioned Karadžic that they had agreed on the procedural rule of providing the courtroom with translations, and Karadžc was repeatedly warned to abide by

this agreement. The presiding judge was "surprised and confused" by the lack of translated documents, and suggested the bench might "make a finding of violation of court order". Karadžić, however, shrugged off these complaints and went right

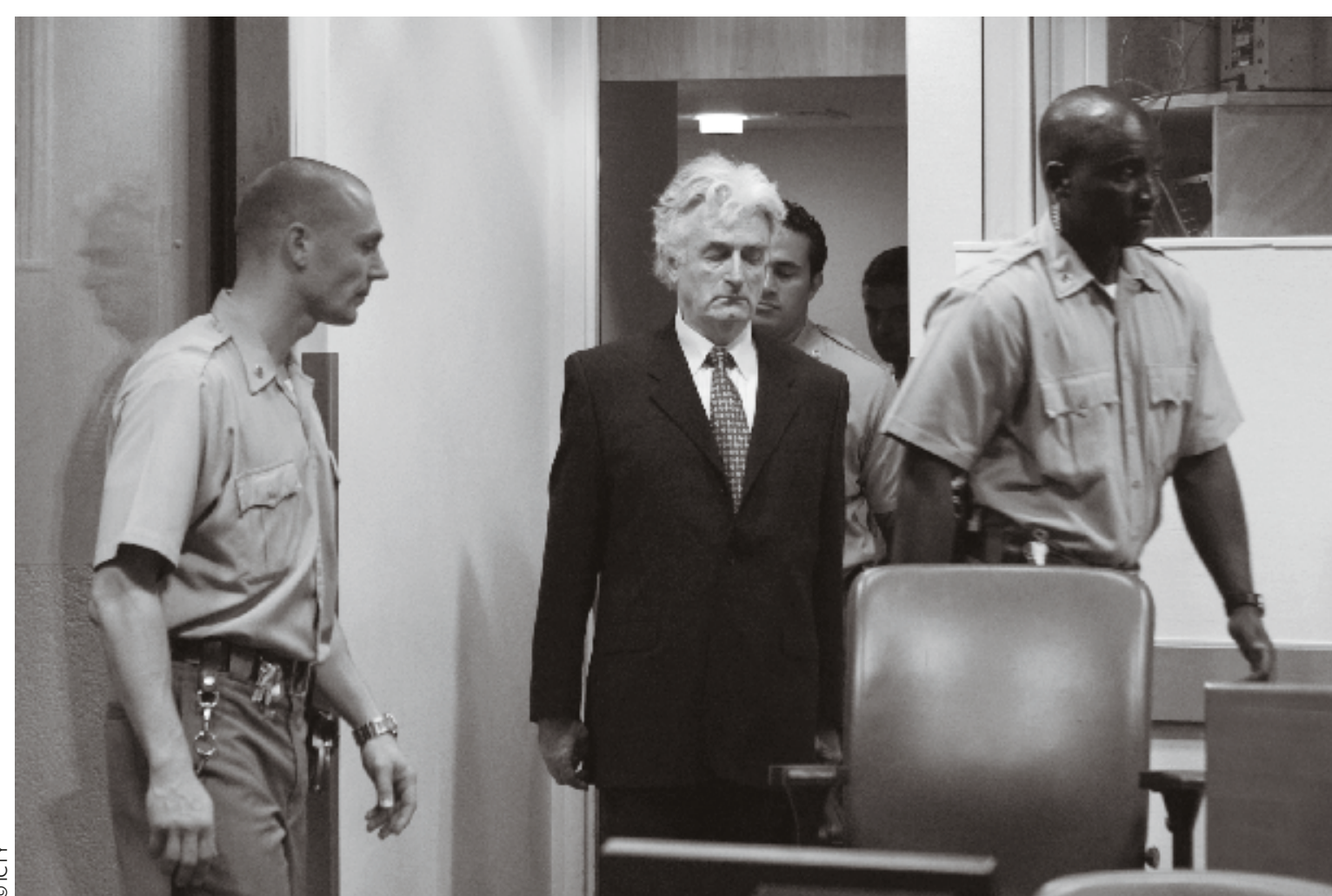

on tendering both translated and untranslated documents, with the excuse that the pace was killing him and the demands of translation could jeopardize his health. The lack of translation was a constant theme during the trial. Karadžić would read the untranslated document aloud and the interpreters in the booth would interpret it on the spot ${ }^{9}$ Witnesses who could not read the document in the original interinal language Karadžic's strategy disadvantaged judges and prosecutors - faced with all those documents (the majority) that were not, originally, in English, and was a serious challenge to witnesses who were unfamiliar with the language of the original document when they were asked to comment on it. This also meant that the accused was essentially performing the document with his reading, placing emphasis where he chose to.

The trial followed earlier trials that had relied on many of the same documents, so quite a few of the translations were, in fact, readily available in the ICTY database. Karadžić and his staff appear to have made little effort to locate them, and the prosecutors went off on translation hunts mid-hearing. The Office of the Prosecutor hrolped Karadžćlocate translations so often that he appeared to have come to expect helpe Kar make the effort to do so himself as the rather imperious tone in this quote suggests:
- Radovan Karadžić at his il July 2008.

(8) We refer to the transcripts (12622)

(9) The court would not accept booth interpretations
of a document as the official to the withess in this way were
marked for identification, and only once the Chamber was provided with an official
translation would the judges translation would the judges
consider admitting the documen to the witness in this way were
tons 
THE ACCUSED: [Interpretation] If there is a translation, it would be useful to have it, for the sake of the other participants, so we don't need to waste time reading aloud, for the sake of the interpreters.

(Transcripts from 12 October 2010, 7767)

Cross-examination without a translation was a serious burden for any witness who had been asked to attest to the credibility of the document that was being read to them via the interpreters. The witnesses were expected to provide their comments based solely on what they could hear over the earphones and - if they knew Eng$\mathrm{h}$ - by watching the English-language interpretation scroll by on the monitor. ${ }^{10}$ The quotes that follow are from Prosecution witnesses (one BCS ${ }^{11}$ native speaker, one protected witness, and three native speakers of English) who are being cross-examined by Karadžić and find themselves in this situation.

THE WITNESS:A. Well, in -- in truth, I can't -- I wouldn't be able to confirm it unless I compared it with the other one, and this does not have an English translation. So I don't want to verify that it is on the basis of those other articles unless I was able read it. I'm sorry

THE ACCUSED: $Q$. You have it in the transcript. I translated it for you, the gist of the agreement that you attended. (...) Does this content that you have in the transcript correspond to the contents of the document of the agreement the signing of which you attended? the contents of the document of the agreement the signing of which you attended?
THE WITNESS: A. If (...) your direct translation is, in fact, a direct translation. I simply don't know. Thave learned in my experience that documents can be translated, interpretations can be given. I've --I've suffered as a consequence of that. So I'm not denying your translation, $\mathrm{Mr}$. Karadzic. I'mjust saying that I don'tsee it because I can't read Serbo-Croat. It's as simple as that. THE ACCUSED: $Q$. I was reading in the Serbian and the translation was given by the interpreter

(10) The transcript, sometimes
referred to as the court record eferred to as the court record,
at the ICTY is typed by a court reporter in real time with only a English-language transcript scrolls across the monitor that stands before each person. If a witness hasn' heard what someone sal
(and knows English), they can wait a moment and then see the

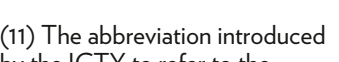
overlapping languages of Bosinan, Croatian, and Serbian. signals that the borths work across all three languages: the interpreter might be speaking
one of the three to interpret for someone using another of the three. The languages are kindre

(Transcripts from 27 May 2010, 2894-5; PW Colm Doyle)

WITNESS: A. Dr. Karadzic, I'd like [you to] show me the document if you could that says this. I'm kind of stuck here just following your words and the translation of your words. I'd sure prefer to be looking at a document.

(Transcripts from 2 June 2010, 3254: PW Robert Donia)

WITNESS: A. Well, I could answer your question if I had a translation into English of the text.

(Transcripts from 29 June 2010, 4308; PW KDZ-185)

WITNESS: A. (...) I can't comment further. Unless it's translated, I won't comment.

(Transcripts from 15 September 2010, 6879; PW Francis Roy Thomas)

WITNESS: A. The way you present it here, I don't accept it, because yoưre translating from English a document which I don't have before me.

(Transcripts from 4 November 2010, 9105; PW Emir Turkušić)
Karadžić is manifestly indifferent to the potential lack of understanding on the part of the Prosecution witnesses.

\section{THE WITNESSES AND TRANSLATION}

Eyewitnesses who testified before the Tribunal for both the Prosecution and the Defence came from all walks of life from Sarajevo, towns, villages, rural areas. Among their number were housewives, farmers, members of police forces, the military, political parties, doctors, writers, journalists, and even several accused who had been tried by the Tribunal and were either awaiting their sentence or serving it. Among the witnesses for both parties there were also foreign observers who had served as monitors during the war, diplomats, UN representatives. Eleven ICTY in-house experts and seven members of the Bosnian Serb armed forces testified for the Prosecution, while 64 members of the Bosnian Serb armed forces testified on Karadžić's behalf. In addition to eyewitnesses, twenty-one expert witnesses testified in the Karadžić trial, twelve for the Prosecution and nine for the Defence, presenting forensic reports on history, ballistics, the military and policing, weaponry, engineering archaeology, forensic anthropology, pathology, and demographics. Roughly 50\% the Prosecution witnesses and 95\% ( of the witnesses summoned by Karadzic were speatian,

A study conducted by the author of eight earlier ICTY trials suggests that of all those taking part in the trial, the witnesses commented the least on translation and interpreting issues. The explanation for this was that "unlike the judges, attorneys, interpreters, and court management staff, the witness (except for the forensic expert) is not in the courtroom as a professional, and more often than not knows little or no English so cannot read the court record as it scrolls by on the video monitor" (Elias-Bursać 2015, 165). The research conducted for this article, however, showed that at least as far as the Karadžić trial is concerned, this assessment no longer applied.

The numbers do not suggest that eyewitnesses, particularly BCS-speakers, were reluctant to comment on the translation. Roughly $40 \%$ of all Prosecution and Defence witnesses, and even some protected witnesses, engaged with issues of translation or interpreting. The same percentage applies to Bosnian, Croatian, and Serbian speakers. Not surprisingly there were much higher percentages of translation and interpreting comments coming from the expert witnesses (75\%) and ICTY in-house witnesses (82\%), all of them courtroom professionals and proficient in English. The highest percentage (88\%) applied to those witnesses who were ICTY defendants with previous trial experience and well-versed in courtroom procedures and the experience of having their words interpreted. Of the 1392 substantive transtion ( witnesses 


\begin{tabular}{|c|c|c|c|}
\hline \multirow[t]{2}{*}{ Prosecution Witnesses } & \multirow{2}{*}{$\begin{array}{l}\text { Appearing } \\
\text { in court }{ }^{\star *}\end{array}$} & \multicolumn{2}{|c|}{$\begin{array}{c}\text { Engaging with } \\
\text { translation / interpreting }\end{array}$} \\
\hline & & number & percentage \\
\hline Witnesses & 195 & 73 & $37 \%$ \\
\hline \multicolumn{4}{|l|}{ of whom there are: } \\
\hline Eyewitnesses* & 116 & 46 & $24 \%$ \\
\hline Expert witnesses & 12 & 9 & $75 \%$ \\
\hline ICTY in-house experts & 11 & 9 & $82 \%$ \\
\hline Protected witnesses & 56 & 9 & $16 \%$ \\
\hline Testifying in closed session & 15 & \multicolumn{2}{|c|}{$\mathrm{n} / \mathrm{a}$} \\
\hline Members of the Bosnian Serb armed forces* & 7 & 3 & $43 \%$ \\
\hline ICTY defendant serving his sentence & 1 & 1 & $100 \%$ \\
\hline Women* & 11 & 3 & $30 \%$ \\
\hline BCS speakers* & 74 & 30 & $40 \%$ \\
\hline Speakers of other languages* & 61 & 43 & $66 \%$ \\
\hline
\end{tabular}

Before they come to court, often many years before, ICTY eyewitnesses give an initial interview through an interpreter to an investigator about their wartime experiences. As soon as the eyewitnesses enter the courtroom to testify they are confronted with translation issues. The parties go over the interview with them: first the party that summoned them so they can tell their story and then the adversarial party questions the credibility of the testimony. Translation and interpreting issues often come up at this stage because a witness would initially give the statement orally in their own language. The investigator would write down what they hear orally, in the rew throught the inters witness in therlangution by the adversarial party is often quite contentious (Elias-Bursać 2015, 168-169);

THE WITNESS: A. I didn’t write this. I was speaking. I was telling the investigators, and they were writing it down. I don't know how they understood it in the English. I don't know. THE ACCUSED: Q. ....) It's evident that the witness has now said that he didn't write this. THE WITNESS: A. No, no, no, no, I don't expect you to direct me. I signed this statement. It was read back to me in the English and in the Bosnian. (...) the allegation doesn't stand that somebody chose these words for me.

THE ACCUSED: $Q$ Witness, sir, who selected the words, the information?

THE WITNESS: A. Sir, I spoke in the Bosnian. I'm not an expert in English. I don't know

\begin{tabular}{|l|c|c|c|}
\hline \multirow{2}{*}{ Defence Witnesses } & \multirow{2}{*}{$\begin{array}{c}\text { Appearing } \\
\text { in court }^{* *}\end{array}$} & \multicolumn{2}{|c|}{$\begin{array}{c}\text { Engaging with } \\
\text { translation / interpreting }\end{array}$} \\
\cline { 3 - 4 } & 238 & number & percentage \\
\hline Witnesses & & 94 & $40 \%$ \\
\hline
\end{tabular}

\section{of whom there are:}

Eyewitnesses*

\section{Expert witnesses}

ICTY defendants still on trial or serving

sentence

Protected witnesses

Testifying in closed session

\begin{tabular}{|l|c|c|c|}
\hline Testifying in closed session & 1 & \multicolumn{2}{|c|}{ n/a } \\
\hline Members of the Bosnian Serb armed forces* & 64 & 28 & $44 \%$ \\
\hline ICTY in-house experts & 0 & \multicolumn{3}{|c|}{ n/a } \\
\hline Women* & 4 & 2 & $50 \%$ \\
\hline BCS speakers* & 212 & 90 & $42 \%$ \\
\hline Speakers of other languages* & 12 & 4 & $33 \%$ \\
\hline
\end{tabular}

Speakers of other languages*

* This information is not available for all protected witnesses, so they are not included in the figures. ** These numbers refer only to witnesses who testified live in court. In addition to these, there was evidence
tendered from another 152 witnesses in writing. how the interpetertat I (Transcripts from 1 March 2011, 12631-12632; PW Eset Muračevic)

Witnesses were also faced with their testimony in earlier trials and asked to comment on the English translation of what they'd said:

THE PROSECUTOR: Q. You previously testified before this Tribunal over five days in January 2006 in the case of Momcilo Krajisnik. That's correct?

THE WITNESS: A. Yes. Yes, that's correct.

THE PROSECUTOR: Q. Have you reviewed that transcript at any time since you testified? THE WITNESS:A. Well, yes and no. Since it was first translated from Serbian into English and then from English back to Serbian, some sentences make no sense, but I do recall this, that testimony.

THE PROSECUTOR: Q. Mr. Savkic, the short answer to that would have been yes. You have reviewed it. That's correct?

THE WITNESS: A. Yes and no.

(Transcripts from 15 February 2013, 33747; DW Tomislav Savkić)

Eyewitnesses may well have felt more comfortable raising or responding to translation issues in the numbers found by this research because many testified in earlier trials. No longer as awed by the experience of appearing in the courtroom, they were able to exercise more agency. Indeed one even finds witnesses who conthey were able to exercise more agency. Indeed one even finds witnesses who con- 
THE WITNESS: [Interpretation] I agree with the gist, and of course I would repeat the same thing, perhaps not word for word the way it was said then. But there is one problem in the interpretation, at least that's how I heard it. In the part which says that the Army of Republika Srpska was in the pursuit stage, you cannot translate it like that, "u fazi progona". I don't know English, so perhaps you can look at that and correct it.

(Transcripts from 27 June 2013, 40560; DW Mirko Trivić)

\section{TRANSLATION INTERVENTIONS}

In addition to his strategy of reading documents aloud, Karadžić frequently made suggestions for the wording of translations and the interpreting as recorded in the transcript. Defence counsels in Tribunal trials are tasked with monitoring translation and interpreting quality (Elias-Bursać 2015, 197-199). Karadžić did so with relish. Yet despite his evident mastery of English, most of his language-based interventions had little or no linguistic foundation. ${ }^{12}$ Indeed they often seemed to be timed as to divert attention from the Prosecutor and the witness at a particularly damning moment of testimony, such as this one where the testimony discusses the expulsion of the Muslim population by Serbian forces:

JUDGE KWON: Mr. Karadzic, is it your argument that the last sentence of para 2 in this document [is] wrongly translated? Because the document says: "The Muslim population of the area of Lisnja village has been expelled."

THE ACCUSED: [Interpretation] That is a mistranslation, and it completely change the meaning.

JUDGE KWON: No, but you --

THE ACCUSED: [Interpretation] It is not expelled.

JUDGE KWON: Your reading of B/C/S was translated as "expelled". So we'll checkit later. THE ACCUSED: [Interpretation] Well, let the interpreters tell you now whether there" a difference between "expelled" " "proterano" "preseljeno" "iseljeno", these three terms "expelled", "restled" " "moved out", is there a differenc? "expelled, resetled",

JUDGE KWON: Why don't you read out the last sentence of para 2 in this document.

THEACCUSED: [nterpretation] "In the area of Derventa there is still artillery fire from time

to time, while in the area of the village of Lisnja, due to the fact that Muslim extremists did not surrender their weapons, the Muslim population was moved out." That's it, "moved out" (Transcripts from 22 November 2011, 21756)

Certain terminological disputes came up often through the four years of trial such as the preference of the accused for the term "encirclement" rather than "siege". He frequently challenged terms for "prisoner" "prisoner of war" "captive", as well regarding terminology.
THE ACCUSED: Q. Up until the moment when you were taken prisoner, do you agree that a criminal is arrested, but a fighter, an honest man, is taken prisoner, so you did not explain it properly here?

THE WITNESS: A. Well, I explained specifically what it meant to be taken prisoner. They simply cut off the column. I was with this group of people who remained in the village, and I was taken to the barracks of the Yugoslav People's Army, and that, in a way, was one of the first camps that were established for the inhabitants of my municipality or rather, my local commune.

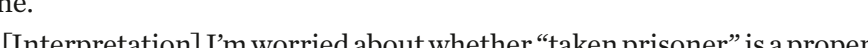

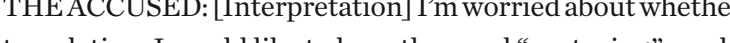
(T) ring" used.

(Transcripts from 1 March 2011, 12717, PW Eset Muračević)

Even some witnesses whom Karadžić summoned for his defence resisted the pressure of the accused to accept his preferences, as demonstrated by the exchange that follows with witness Vujadin Popović who had been tried by the ICTY and sentenced to life for war crimes and genocide (now serving his sentence in Germany)

THE WITNESS: [Interpretation] A. (...) UNPROFOR check-points are under our control and whether they are threatened by our units. (...)

THE ACCUSED Q Thank you. I believe, I'm not sure, that the translation is wrong, that is to say, "threatened by our units", I would say or "are in jeopardy from our units", but I'm not sure. I'm not sure about this translation, whether they are really threatened by our units or -- it's better for you to read it. [From:] Under our control. You can read it and we can ask the interpreters to literally interpret it. (...)

THE WITNESS: A. It says clearly here: "Inform us urgently whether the UNPROFOR check-point in Biljeg is still under our control there, which other UNPROFOR check-points are under our control or if they are threatened by our units, or if they are threatened by our units. And likewise, urgently tell us what lines were reached along the axis of our unit's attack" That's what it says.

(a)

THE ACCUSED: Q Thank you I stick to my objection that "threatened" is wrong and that it should be that they are in jeopardy (..)

(Transcripts from 5 November 2013, 43020; DW Vujadin Popović)

It is not entirely clear in this last example whether Karadžic is admonishing Mr. Popovic or battling with the interpreterwho was translating Mr.Popovic's testimony and persisted in translating what the witness said as "threatened".

The research found over 170 instances of Karadžićs interventions over what he contended were mistranslations. 57 complaints about the translation or interpreting interrupted the prosecutor mid-examination. There were 89 complaints about the wording of a translation. A search among the court records on the ICTY website (ICTY Court Records) indicates that there were only four formal submissions from 

Conference and Language Services Section. If Karadžić complained mid-session 89 times about the wording of a translation yet only submitted four formal complaints one cannot help but conclude that his interventions were less about substance than about asserting his ownership of the proceedings.

\section{- Radovan Karadžic}

at his first further

initial appearance,

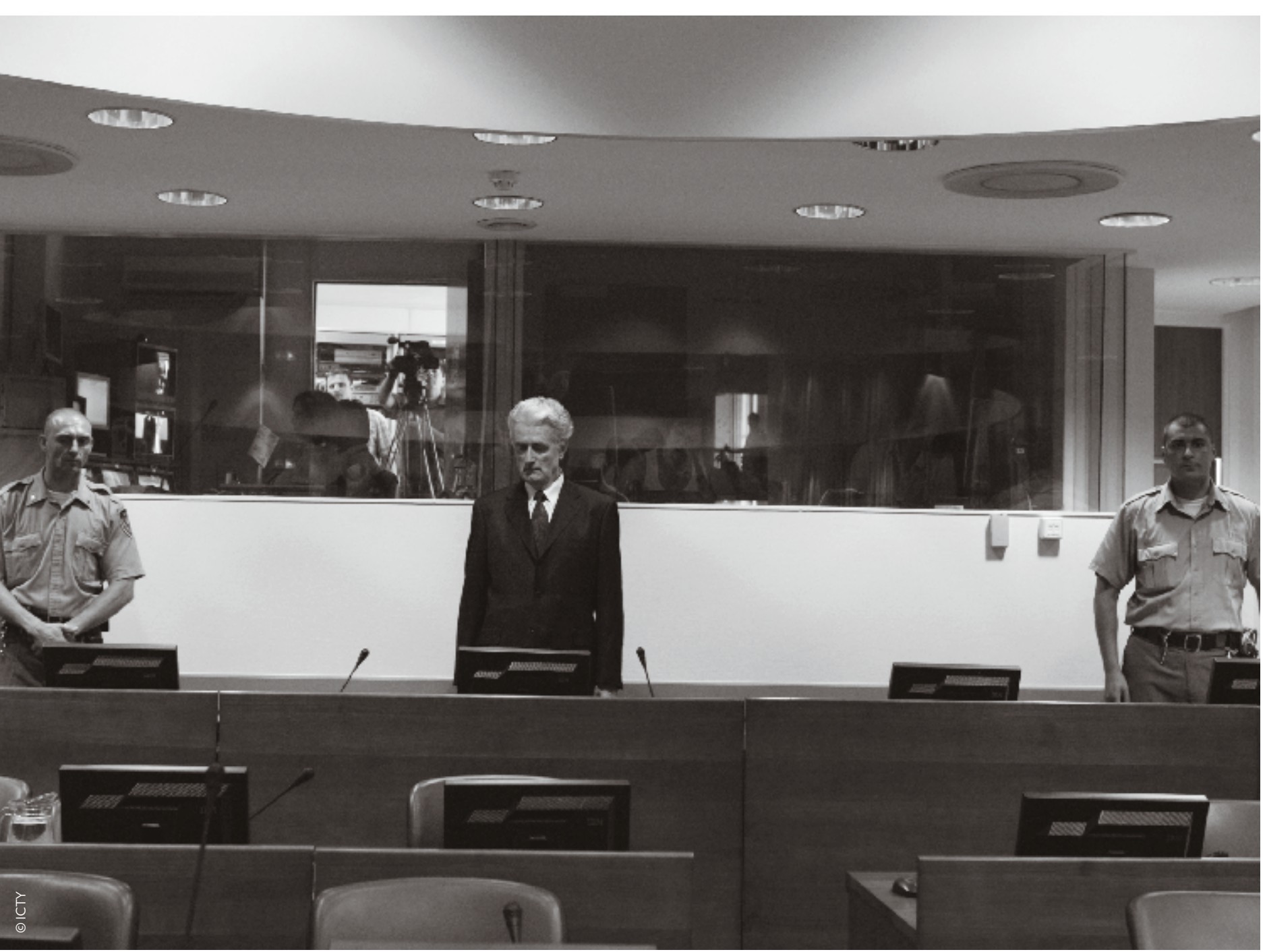

\section{CONCLUSION}

The degree to which Karadžić strove to make this trial his story recalls James Dawes thoughts on the key role language plays in war crimes, silencing opponents and victims while filling the void with noise. Karadžic opted for agency with his choice to act as his own defence counsel and conduct all cross-examination himself. Then he went farther, reading documents out loud. And he peppered the courtroom sessions with language interventions and corrections insertinghimselfinto witness sessions with language interventions and corrections, inserting himself into witness
testimony.

There are so many things transcripts cannot convey: emotion, gesture, attitude, tension. But from the significant number of witnesses that engaged with translation and interpreting in this ICTY trial, we can conclude that they showed resistance and resilience, bravely facing Karadžić's attempts to impose himself on their testimony.

\section{POSTSCRIPT}

Shortly after this article was completed, the ICTY chamber issued its 2615-page judgement on 24 March 2016, sentencing Radovan Karadžić to 40 years in jail. The Chamber upheld all counts of the indictment except one of the two counts of genocide. As to references to translation and interpreting in the judgement, a search similar to the search conducted through the transcripts (using the cluster "transl") found 25 references of which four are found in the body of the judgement, and the rest are 25 references of which four are found in the body of the judgement, and the rest are logical points Karadžić held to be salient to his defence, particularly a dispute over whether a certain phrase referred to "expelling" Muslims or "pushing" them "back" (Prosecutorv. Radovan Karadžic, f.n. 7352, 855). The Chamber refused to treat these terms as substantively distinct. Similarly when the word iseljavanje was translated as "evicting", and the Defence called for it be translated as "moving out at their request", the Chamber considered that in the context of the document in question the meaning of the two translations was effectively the same (Prosecutor, fn 10706 年 1258). memorandum that gives the proper translation as "ifting the blockade "rather than lifting the "siege" (Prosecutor, f.n.11605,1379). The rest of translation-related issues refer to corrections of typographical errors such as dates; the spelling of proper names; or particulars of evidentiary documents. Only two of these, the dispute over "expel" vs. "push back" and the preference for avoiding the word "siege" are points Karadžić insisted on during his trial. Otherwise, none of Karadžić's many linguistic interventions were considered to be of substantive significance in the judgement. After the sentence was read out, at the court session itself, Karadžić was heard to exclaim that he was astonished by his 40-year sentence. Purportedly he had "already excked his bags, so certain he was that he would acquitted". In "Radovan Karadpack “C zic's 'Catalogue of Gentatus 
Pushing Back (continuation) the conclusion notes, "[i]nterestingly, after the trial verdict, [Peter] Robinson was promoted from legal adviser to defense counsel" (6 April 2016). In other words, following the crushing defeat of his strategy of creating a curtain of noise to silence and shape the testimony of the witnesses, Karadžić withdrew from conducting his own defence, relinquishing to Robinson the responsibility of pursuing the defence during his appeal.

\section{WORKS CITED}

- Case Information Sheet, United Nations International Criminal Tribunal for the former Yugoslavia, http://www.icty.org/x/cases/karadzic/cis/en/cis_karadzic_en.pdf (accessed 29 February 2016).

- Clark, Janine Natalya, Judging the ICTY: Has It Achieved Its Objectives?', Southeast European and Black Sea Studies 9(1-2), 2009, 123-142.

- Dawes, James, That the World May Know: Bearing Witness to Atrocity, Cambridge: Harvard University Press, 2007.

- Donia, Robert, Radovan Karadžić: Architect of the Bosnian Genocide, Cambridge: Cambridge University Press, 2015.

- Elias-Bursać, Ellen, Translating Evidence and Interpreting Testimony at a War Crimes Tribunal: Working in a Tug-of-War, London: Palgrave, 2015.

- ICTY Court Records. United Nations International Criminal Tribunal for the former Yugoslavia, http://icr.icty.org (accessed 29 February 2016).

- ICTY Rules of Procedure and Evidence, http://www.icty.org/x/file/Legal\%20Library/Rules_procedure_ evidence/it032rev46e.pdf (accessed 23 May 2016).

- Prosecutor v. Radovan Karadžić: Public Redacted Version of Judgement Issued on 25 March 2016, http://www.icty.org/x/cases/karadzic/tjug/en/160324_judgement.pdf (accessed 22 April 2016).

- 'Radovan Karadžićs's “Catalogue of General Complaints”', Sense Tribunal, 6 April 2016, http://www.sense-agency.com/icty/radovan-karadzicx9 (accessed 29 April 2016).

- Stover, Eric, The Witnesses: War Crimes and the Promise of Justice in The Hague, Philadelphia: University of Pennsylvania Press, 2005.

- Transcripts of Open Sessions of the Karadžić trial, http://www.icty.org/case/karadzic/4\#trans (accessed 23 May 2016).

- United Nations International Criminal Tribunal for the former Yugoslavia, Trial Judgement Summary for Radovan Karadžić, 24 March 2016, http://www.icty.org/x/cases/karadzic/tjug/en/160324_judgement_summary.pdf (accessed 29 April 2016)

- United Nations International Criminal Tribunal for the former Yugoslavia, http://www.icty.org (accessed 29 February 2016). 